\author{
Svetlana Tomić \\ Faculty of Foreign Languages \\ Alfa BK University, Belgrade, Serbia \\ tomic.svetlana@gmail.com
}

\title{
WOMEN INTELLECTUALS IN SERBIAN 19TH CENTURY CULTURE AND THEIR BELIEFS: THE IMPORTANCE OF DISCONTINUITY ${ }^{1}$
}

The subject of this paper is the analysis of fiction and nonfiction of significant women intellectuals who lived in Serbia and in the Austro Hungarian Empire in the second half of the 19th century, the time defined by many historians as a key period of modernisation of the Serbian society. Savka Subotić, the Queen of Serbia, Natalija Obrenović, as well as the first teachers and writers such as Stanka Glišić, Draga Gavrilović, and Mileva Simić, and an actress Milka Aleksić Grgurova, in their literary works presented beliefs which were contrary to the prevalent society dogma. They believed that the education of women was a necessary element of a society's progress, challenging the rulling patriarchy. At the same, being aware of where the power of conservatism is, they understood that the success of women's emancipation is possible in the future only if men become emancipated. They also hold the view that marriage without mutual love and respect will be dysfunctional and they approved marriage between people of diferent national origin, almost a heretical position in Serbia at the time. The main thesis of this paper is that the discontinuity in belief as a fundamental part of the society's modernization of the ninteenth century Serbia came from women intellectulas.

Key words: belief, women's education, emancipation of women, Serbian literature, history of Serbian society.

Individual freedom begins with the right to choose one's own belief. The beliefs of intellectual women about women and society reflect the process of conquering new expanses of women's freedom and women's fight for positive views of their own subjectivity. This paper will present the beliefs of women intellectuals who disconnected themselves from traditional ways of thinking about women as they advocated for the emacipation of Serbian society. While

1 This paper was presented at the 51th Annual ASEEES Convention, November 23-26, 2019, San Francisco, California. I thank The North American Society for Serbian Studies, The Ruzica Popovitch-Krekic Special Fund, and The Dr. Gojko Vuckovic Memorial Fund for the generous travel grant. 
at the same time a small group of men in Serbia expressed some liberal views on women and their emancipation, women's liberal views were more elaborated and contributed more to the development of intellectual culture.

The group of women I have identified was a part of an important cultural change as Serbian women emerged on the public stage and began creating their own positive image. The discovery of a woman's belief system helps to better understand their subjectivity, which official historians have ignored for a long time. Additionally, it allows us to examine more carefully the durability, problems and failures of the modernisation process, and to notice connections with current challenges and opportunities for democracy. Although this discontinuity of traditional beliefs formed the main plot of the democratisation of Serbian society, it was excluded from official "historical narratives" for ideological reasons. ${ }^{2}$ Official historians instead insisted on the idea of a continuity of traditional development of Serbian society, where men are the only politically visible actors. They further developed the process of "inventing the tradition" 3 only of great men, which obscured the important link between women's education and growing feminism and also clouded the knowledge that women played a bigger political role than earlier presented. Such strategies have reinforced conservatism - misogyny, patriarchy and national chauvinism which still place a burden on Serbian education and society.

In both Serbian and English, the word "belief" has similar meanings: 1. something that is accepted, considered to be true; 2 . an opinion or conviction; 3. a religious tenet. ${ }^{4}$ In this paper I use the word "belief" in the context of unofficial belief which belongs to an individual consciousness, to the private and subjective sphere of life, and which is expressed in writing and behavior. ${ }^{5}$ I will discuss belief as a way of thinking, as a statement which a person formulates by using his or her own experience. Thus, the belief is a part of "personal epistemology," of an individual's knowledge and process of knowing (Pintrich 2002). It reflects freedom to think independently of current norms, and therefore it can be understood as a contrast to a closed society that restricts human development. For these reasons, one of the crucial elements of believing is creating visions of alternative futures, or finding the solution of social problems. ${ }^{6}$

2 For more details on the place of historiography in narrative, see Hayden White "The Structure of Historical Narrative", originally published in 1972 (White 2010: 112-126).

3 The term was coined by Eric Hobsbawm (1917-2012), British historian, in the collection of essays The Invention of Tradition (1983) co edited with Terence Ranger. On the relationship between famous Serbian and South Slavic women and women writers from the $19^{\text {th }}$ and $20^{\text {th }}$ century, past, memory, and history see Tomić 2018 .

4 Compare Rečnik srpskohrvatskog jezika 1967: 355 to Merriam-Webster 2008: 138. "Semantically, 'belief' as distinct form knowledge carries the connotation of disputability - the believer is aware that others may think differently" (Abelson 1979: 356). Quite often theoreticians discuss the relationship and contradictions between knowing and believing (Hahn 1973; Österholm 2010a; Кинђић 2012/134: 388-394).

5 More details on private beliefs, see Šušnjić 1995: 250-263.

6 On other characteristics of belief, see Abelson 1979: 355-366. 
Describing beliefs is important because it points to the personal consciousness, it reflects the behaviour (Österholm 2010b: 35-36) and affects personal goals, standards, and strategies (Hofer and Bendixen 2012: 235). Theoreticians underline the fundamental role of believing in creating attitudes and emotional responses (Abelson 1979; Speer 2005).

While some of the women intellectuals discussed in this paper, such as Savka Subotić, Draga Gavrilović and Mileva Simić lived in the Austro Hungarian Empire, others, for example Queen Natalija Obrenović, Stanka Glišićeva, and Milka Aleksić Grgurova lived in Serbia. ${ }^{7}$ They originated from different classes, nations and religions, and had different levels of education, political power, social mobilities, and social networks. In researching their statements and the belief system I have applied a "contentive analysis of a belief system", using the method suggested by Robert A. Hahn (1973). I started by selecting burning issues of the19th century debates on women and social norms from historical, pedagogical, sociological, and literary research because identifying a theme is one of the most fundamental tasks in qualitative research (Hahn 1973: 219). As sources I used women's fiction (stories, novels, and aphorisms) but also their documentary/"ego" writings, such as autobiographies, memoirs, diaries, letters, public lectures... Some of the writings were published during their lives, but some appeared 100 years later. Despite this overdue emergence, women's beliefs help understand their character and the relationship between their words and actions, which can define their beliefs as true or false. ${ }^{8}$

In order to understand the relationship of the dominant political norm to women I used the Serbian Civil Law (1844-1946), where the position of women remained low for a long period of time. A woman was seen as a marginalised member of society, without rights, subjugated to men and viewed as an object, which in real life translated to many forms of violence. ${ }^{9}$ This view of women can be also noticed in common law described thoroughly in Serbian folk proverbs and sayings, where "women were denigrated whenever there was an opportunity“ (Šljivić Šimšić 1980: 41).

Recent research conducted by a historian Ana Stolić (Столић 2015: 23-71) has shown that in the mid 19th century a group of men appeared who expressed some liberal views on women. My research takes a further step by exploring the views of "new women" who filled up many gaps in the ongoing debates.

7 For more details about Savka Subotić see Šljivić Šimšić 1993; Столић 2001; Стојаковић 2018. For details on Draga Gavrilović see Миланков 1989; Миланков 1990; Tоmić 2008; Томић 2013. About Simić, see A. B. 1913. For more details about kraljica Natalija Obrenović see Trgovčević 2015; Tomić 2015a; Tomić 2015b; Tomić 2016; Tomić 2020. For more details on Glišić see Магазиновићева 1913. Some new and major studies on Grgurova include Црвенчанин 2003; Михаиловић 2011; Томић 2014в; Томић 2014г. On the importance of Serbian women writers at the beginning of the 20th century, see Hawkesworth 2000 and Koch 2007 as well as their translated studies in Serbian (Hoksvort 2017; Kox 2012).

8 For more details, see Hahn 1973: 214-217; Österholm 2010b: 39.

9 For more on the position of women, see Draškić andPopović-Obradović1998: 11-26. Women's statements about violence against women are presented in Popović 2017. 
For example, according to Stolić, some men defended the need for women's education. Stevan Popović, Dimitrije Matić, and Milan Đ. Milićević saw the purpose of women's education in improving motherhood and domesticity. In contrast, Alimpije Vasiljević held a view similar to that of socialist Svetozar Marković, that women's education offers the possibility for women's emancipation. Other controversies can be noted in regard to women's political participation. For example, the political party United Serbian Youth allowed women to become members but not to actively participate in its work. Similar to Alimpije Vasiljević, Vladimir Jovanović recognised gender inequality and argued for a woman's need to choose her own marital partner. Jovanović sharply criticized fashion and its oppressive beauty system, a critique that was later elaborated by Svetozar Marković. Differing from many liberals, Marković was the first Serbian intellectual who perceived a woman as an autonomuous and independent individual who has citizenship rights (Столић 2015: 59).

While traditional belief imposed a view that the nature or biology defined women's rights and freedom, Savka Subotić held the opposite view, and explicitly accused men of limiting women's rights and freedom ("women's rights and freedom were defined by a man because of his power" (,muškarac i to pravom jačeg“, cited in Стојаковић 2018: 62). In one aphorism, Subotić underlined that humanism is "equal to feminism" (cited in Стојаковић 2018: 67), and in an another aphorism she wrote: "If you give women more freedom, more knowledge and provide them a more healthy lifestyle, society will blossom"/ „Dajte ženama više slobode, više znanja i više zdravlja, pa će narod procvetati“, cited in Стојаковић 2018: 56). ${ }^{10}$

Female public intellectuals believed that women were important members of society, that their work should be paid, respected and publicly awarded. Some of them, for example Savka Subotić and Queen Natalija Obrenović, used their power to make change happen. Subotić believed that women's economic independence can make a positive impact for future economic and social development. ${ }^{11}$ She noticed the artistic value of peasant women's embroidery, paid them for their work and exhibited it in European cities with great success. In Serbia, in 1876, the Princess Natalija for the first time awarded women publicly with medals for their social services. As noted by the theoretician of belief, Robert P. Abelson, such cases not only prove the drastic discrepancy between different belief systems, but also the fact that there is no common content core, which further creates a disturbing social tension (Abelson 1979: 361). ${ }^{12}$

10 All translations from Serbian to English are mine unless otherwise indicated.

11 Стојаковић 2018: 56-70.

12 For example, throughout 19th century, during war time the state appreciated women's voluntary work as nurses but in peace time, despite the enormous need for educated nurses, the officials did not establish formal nursing education, thus refusing to institutionaly introduce a new profession for women and strenghten their economic independance. Women fought more than half a century in order to get a nursing school and a profession. More details on this issue are provided by Копривица Ковачевић 2018. 
Women intellectuals believed that men had wrong and stereotypical views and contradictory statements about women. At the beginning of her aphorism Queen Natalija Obrenović quoted an old proverb (or perhaps a thought of the French author, Alfred de Musset): "A woman is like a shadow: as you chase her she runs away, and if you run away, she chases after you",„Žena je kao senka: ako idete za njom, ona beži od vas, a ako bežite od nje, ona ide za vama"). Then she added the opposite thought: "The person who said this had never met a proud woman" (,onaj koji je ovo izrekao nije poznavao ponositu ženu“, Obrenović 2015: 263). Savka Subotić's aphorism goes as follows: "Men's thoughts on women are contradictory. That happens because they take only the women they spent their time with as examples.“/,U mišljenjima drugih o ženama nalaze se najveće protivrečnosti. To dolazi otuda što oni obično uzimaju one žene za primer sa kojima se najviše druže“ (cited in Стојаковић 2018: 159).

Not only did women criticize men, they also condemned lazy and manipulative women, who showed no self-repect, and used patriarchal standards to perpetuate the status quo. While traditional beliefs impose a woman's beauty as her value, women intellectuals valued women's power of thinking and their public actions. They valued a woman's personality, especially pride, or women who showed self-respect, dignity, importance or superiority. Quite often they wrote about their pride. Draga Gavrilović, Mileva Simićeva, and Milka Grgurova created new literary types of women intellectuals. ${ }^{13}$ Draga Gavrilović openly defined the traditional belief about women as "a rotten taste, or opinion" that men spread from speaking to writing, which spoiled young girls and people in general (Гавриловић 2007: 91). Gavrilović also believed that a woman's beauty is "a vague idea; it may reflect personal taste, but the development of the cosmetic and pharmaceutical industry as well“"/(...) lepota je relativan pojam.Ona je stvar ukusa. Neki vele i industrije, pa i apoteke...“ (Гавриловић 2007: 254-255). Her thoughts were much ahead of her time, and would be elaborated later by other feminist theoreticians (Mac Canell D. and Mac Canell J.F. 1987; Bartky 1990).

At the time, debates on the need for women's education intensified. In public, for a long time, a negative view reflected the fear of disturbing the economic power of men on the labor market, which they dominated. Savka Subotić and Queen Natalija defended the opposite view. They valued educated women and used their own power to establish and support educational institutions for women, in Novi Sad and Belgrade. ${ }^{14}$ Subotić, Obrenović, and Glišićeva considered autodidacticism or self-education an important intellectuals' trait. ${ }^{15}$

13 For further reading on their literary contributions, see Tomić 2008, Tomić 2011,Tomić 2012, Tomić 2014a i Tomić2014b.

14 On the impact of Natalija Obrenović on the Belgrade High School for Girls, see Станков 2011.

15 Savka Subotić was recognised as a great speaker both locally and internationally. Recent research has shed light on Subotić's philosophical contributions (Стојаковић 2018). On Subotić's and Obrenović's literary talents, see Tomić 2015, Tomić 2016. 
In Subotić's words, "self-education is the best school for personal development of inner strenght of every person“/, ,najbolja škola za individualan razvitak duševne snage svakog čoveka" (cited in Стојаковић 2018: 175). Stanka Glišićeva admitted that the reason for writing her memoir was to inspire young people without substantial financial support to follow her example of self-education, since it was her own key strategy for success (Глишићева 1933: 54).

In women's education women intellectuals saw the potential for society's emancipation. However, for some of them the key factor for successful emancipation was to emancipate men, because they had all the power. This belief was elaborated by Draga Gavrilović in her story-essay "A Letter to a BloodBrother" (Гавриловић 2007: 339-347). At the end of the 19th century, she believed (and now we can see that she was right!) that we would have to wait more than 100 years for that emancipation to happen because men are "not mature enough to live with a free woman"/,,nedorasli da žive sa oslobođenom ženom“ (Гавриловић 2007: 339). We can find this statement true if we read nonfiction and fiction writings on the private lives of Serbian rulers and ministers. 16

Women intellectuals believed in a different type of marriage which was not established by a father's choice and economic situation, but on shared love and mutual respect. Women must have a choice to marry or to stay single, and each of these choices has to be respected. In her literary texts, Draga Gavrilović elaborated this belief. ${ }^{17}$ She went even further when in Devojački roman (A Girls Novel) she changed a prevailing cultural model, by believing that a harmonic multicultural marriage between Germans and Serbs could happen. For other writers, such a solution was percieved as impossible, shameful and unacceptable. Jakov Ignjatović (Večiti mladoženja), Laza K. Lazarević ("Švabica") and Stevan Sremac (Zona Zamfirova) defended the ethnocentric or nationalistic type of marriage and motherhood, meant to protect national politics, language, culture, and ideas. ${ }^{18}$

In conclusion, this subjective type of knowledge helps in better understanding women intellectuals' characters and capabilities, and sheds more light on women's contribution to the public debate on women and emancipation. In the 19th century, they appeared not only as a new social group but also as a group of intellectuals with new beliefs about gender, which discontinued the traditional belief system. This discontinuity is important because it reveals a revolutionary change in society, or a crisis which has been silenced in the official histories of Serbian literature and society. At the same time, the discontinuity points to the problem of change in history which is, as shown by

16 Столић 2015: 41; Tomić 2016; Tomić 2020. More on contemporary gender-related problems and social attitudes, see a case study of Serbian MeeToo movement (Avramović 2019).

17 For example, Draga Gavrilović: Devojački roman, Iz učiteljičkog života; ,, Razume se, onu lepšu“; „Ona je — srce mu kaže“ .

18 According to Nira Yuval-Davis, "patriotic motherhood" is a political choice which biologically and culturally reproduces the nation and gender relations (Yuval-Davis 1997). 
Hayden White, always related to the period when the dominant social group and its cultural code comes under attack and gets its revisions.

Unlike most men, women defended their own gender identity vigorously and with arguments, expressing their own right for dignity and self-fullfilment. While men rarely expressed self-criticism, women viewed self-perception as an important part of any progress. They explicitely criticized men as the only political power responsible for the perilous impact of conservatism. Women's words of believing were congruent with their behaviours and for that reason we can evaluate them as honest and true.

Further research could explore comparisons with women from other European countries and America. One quite interesting research topic is the relationship between private and religious beliefs. For example, in Gavrilović's writings there are many critical thoughts on the religious discrepancy between Serbian priests' beliefs and their practices. ${ }^{19}$ Queen Natalija's religious conversion has remained an insuficiently researched controversy. If we shed light on the beliefs' origin, situations and personal experiences, we will get more information about their context and motivation. In addition, what is the relationship between the beliefs of Subotić and Obrenović and their powerful leadership?20

According to new reports on human rights in Serbia, women's vision of a just and unselfish society has not yet been achieved. ${ }^{21}$ In the 19th century, these women argued for the need to eliminate traditionally negative views on women. However, now, at the beginning of the 21 st cenutry, we can notice the complexity of this problem, because violence against women as well as the violence against any other politically marginalised group (Roma, LGBT, disabled, immigrants...) is still contemporary in Serbia. It imposes the politics of fear and tensions among groups and makes democratic rights and freedom, as ideals, hard to achieve.

\section{LITERATURE}

Abelson Robert. "Differences between Belief and Knowledge Systems". Cognitive Science, 4(1979): 355-366.

Avramović Aleksandra. Potencijal umreženog feminizma u borbi protiv nasilja nad ženama: studija slučaja pokreta \#MeeToo, a paper presented at the international conference $\mathrm{New}$ Horizons of Culture, Arts and Media in the Digital Environment, at the Faculty of Dramatic Arts in Belgrade, September 12, 2019.

Bartky Lee Sandra. Femininity and Domination: Studies in the Phenomenology of Oppression. New York and London: Routledge, 1990.

Beauvoir de Simone. The Second Sex, translated and edited by H.M. Parshley.New York: Alfred A. Knopf, 1971. $42-63)$.

19 Among her other work, see also her satire "Zašto greh napreduje” (Гавриловић 1990b:

20 If interested in the topic on the beliefs of women leaders, I would suggest that researchers start with Sheppard 2017 and Milinović 2017.

21 Helsinški odbor za ljudska prava 2017. 
Draškić Marija and Popović-Obradović Olga. "Pravni položaj žene prema srpksom građanskom zakoniku (1844-1946)“. Latinka Perović (ed.). Srbija u modernizacijskim procesima 19. i 20. veka. .Beograd: Institut za noviju istoriju Srbije), 1998: 11-26.

Engelbrecht A. S, Heine, G., \& Mahembe, B. The influence of ethical leadership on trust and work engagement: An exploratory study. SA Journal of Industrial Psychology/SA Tydskrif vir Bedryfsielkunde, 40,1(2014), Art. \#1210, 9 pages. http://dx.doi.org/10.4102/ sajip.v40i1.1210

Hahn, A. Robert Hahn. "Understanding Beliefs: An Essay on the Methodology of the Statement and Analysis of Belief Systems". Current Anthropology, Vol. 14, No. 3 (June, 1973): 207-229

Hawkesworth Celia. Voices in the Shadows: Women in Verbal Art in Serbia and Bosnia. CEU Press, 2000. Under the title Glasovi u senci: žene i književnost u Srbiji i Bosni the book was translated to Serbian in 2017 by Aleksandra Đuričić. Beograd: Službeni glasnik.

Helsinški odbor za ljudska prava. Realna ograničenja Srbije u izboru sopstvene budućnosti. Beograd. Helsinški odbor za ljudska prava, 2017.

Hobsbawm Eric. The Invention of Tradition, co edited with Terence Ranger. Cambridge University Press, 1983.

Hofer K. Barbara and Bendixen D. Lisa. "Personal Epistemology: Theory, Research and Future Directions“. Karen R. Harris, Steve Graham, and Tim Urdan (eds.) APA educational psychology handbook. Vol. 1, Theories, constructs, and critical issues. Washington, DC: American Psychological Association, 2012: 227-256.

Ignjatović Jakov. Večiti mladoženja. Beograd: Savremena administracija, 1964.

Koch Magdalena. ...kiedy dojrzejemy jako kultura... Tworczosc pisarek serbskich na poczatku XX wieku (kanon - genre - gender). Wroclaw: Wydawnictwo Universytetu Wroclawskiego, 2007. The book was translated from Polish to Serbian by Jelena Jović in 2012

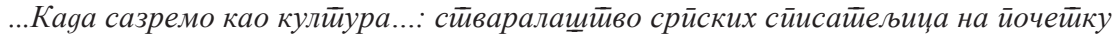
XX века: (канон - жанр - pog). Београд: Службени гласник.

Mac Canell D. and Mac Canell J.F. "The beauty system". N. Armstrong and L. Tennenhouse (eds.) The Ideology of Conduct: Essays on Literature and the History of Sexuality. New York: Methuen, 1987: 206-238.

Merriam-Webster's Advanced Learner's English Dictionary. Merriam-Webster, 2008.

Milinović Jelena. Liderke izbliza: prilog proučavanju liderstva žena u Bosni i Hercegovini. Sarajevo: Sarajevski otvoreni centar, 2017.

Obrenović Natalija. Ruža i trnje: uspomene, aforizmi i priče, prepiska, Ljubinka Trgovčević, Svetlana Tomić and Ivana Hadži-Popović (eds.).Beograd: Laguna, 2015.

Österholm Magnus. "Beliefs: A Theoretically Unnecessary Construct?", Proceedings of CERME 6, January 28th - February 1st 2009, Lyon, France, 2010a: 154-163.

Österholm Magnus. "The Ontology of Beliefs from a Cgnitive Perspective". Furinghetti F. \& Morselli F. (eds.) MAVI-15: Ongoing research on mathematical beliefs (Genoa, 8-11 September 2009), 2010b: 35-46.

Pintrich R. Paul "Future challenges and directions for theory and research of personal epistemology". B. K. Hofer \& P. R. Pintrich (eds.) Personal epistemology: The psychology of beliefs about knowledge and knowing.Mahwah, N.J.: L. Erlbaum Associates, 2002: 389-414.

Popović A. Milutin Zatvorenice: Album ženskog odeljenja Požarevačkog zatvora (1898). Svetlana Tomić (ed.). Beograd: Laguna, 2017.

Simons L.Tony. "Behavioral integrity as a critical ingredient for transformational leadership". Journal of Organizational Change Management, 2(1999): 89-104.

Sheppard Cary Maria. What are the beliefs of women who lead? A Thesis Submitted to the Faculty of Social and Applied Sciences in Partial Fulfillment of the Requirements for the Degree of Masters of Arts in Interdisciplinary Studies Royal Roads University Victoria, British Columbia, Canada, 2017. https:/viurrspace.ca/bitstream/handle/10613/4885/ Sheppard_royalroads_13130_10417.pdf?sequence $=1 \&$ isAllowed $=y$

Speer M. Natasha. "Issues of method and theory in the study of mathematics teachers' professed and attributed beliefs". Educational Studies in Mathematics, 58 (2005): 361-391. 
Šljivić Šimšić Biljana. "The Woman in Serbian Folk Proverbs". Serbian Studies 1 (1980): $41-51$.

Šljivić-Šimšić Biljana. "Savka Subotić (1834-1918), The Mother of Serbian Women's Culture". Serbian Studies 1 (1993): 69-87.

Šušnjić Đuro. Znati i verovati: teorijske orijentacije u proučavanju religije i ateizma. Beograd: Čigoja, 1995.

Tomić Svetlana. "Draga Gavrilović (1854-1917), the First Serbian Female Novelist: the Old and New Interpretations“. Serbian Studies 2 (2008): 167-189.

Tomić Svetlana. "The First Serbian Female Teachers and Writers: Their Role in Emancipation of Serbian Society". Serbian Studies 1 (2011): 57-79.

Tomić Svetlana. Tipologija književnih junaka i junakinja u prozi srpskog realizma iz rodne perspektive.Novi Sad: Filozofski fakultet. Doktorska disertacija, 2012.

Tomić Svetlana Realizam i stvarnost: nova tumačenja proze srpskog realizma iz rodne perspektive.Beograd: Alfa univerzitet, Fakultet za strane jezike, 2014a.

Tomić Svetlana. „Obrazovanje i osvajanje građanskog statusa žena: primeri prvih profesionalnih učiteljica-književnica“. Duhaček, Daša; Lončarević, Katarina i Popović, Dragana (eds.). Obrazovanje, rod, građanski status. Beograd : Čigoja štampa: Fakultet političkih nauka, Centar za studije roda i politike, 2014b: 38-57.

Tomić Svetlana. “Značaj književnih radova kraljice Natalije”. Ljubinka Trgovčević, Svetlana Tomić i Ivana Hadži Popović (eds.) Kraljica Natalija Obrenović Ruža i trnje: uspomene, aforizmi i priče, pisma. Beograd: Laguna, 2015a: 243-255.

Tomić Svetlana."Hronologija života i rada kraljice Natalije Obrenović”.”. Ljubinka Trgovčević, Svetlana Tomić i Ivana Hadži Popović (eds.) Kraljica Natalija Obrenović Ruža i trnje: uspomene, aforizmi i priče, pisma. Beograd: Laguna, 2015b: 469-92.

Tomić Svetlana Doprinosi nepoznate elite: Mogućnosti sasvim drugačije budućnosti. Beograd: Alfa BK univerzitet, Fakultet za strane jezike, 2016.

Tomić Svetlana. Slavne i ignorisane: Ka kritičkoj kulturi pamćenja, Beograd: Alfa BK univerzitet, Fakultet za strane jezike, 2018.

Tomić Svetlana. "Rediscovering Serbian Women's Memoirs: Gendered Comparison in a Historical Context". Teksty Drugie 1 (2020): 124-139.

Trgovčević Ljubinka „Priča jedna kraljice”. Ljubinka Trgovčević, Svetlana Tomić и Ivana Hadži-Popović (ur.). Kraljica Natalija Ruža i trnje: uspomene, priče, aforizmi i pisma. Beogad: Laguna, 2015: 11-47.

Yuval-Davis Nira. Gender \& Nation. SAGE Publications, 1997.

White Hayden. "The Structure of Historical narrative". Hayden White The Fiction of Narrative:Essays on History, Literature, and Theory 1957-2007. Baltimore: The John Hopkins Univerity Press, 2010: 112-126.

А. В. (Аркадије Варађанин). „Милева Симићева“. Српске књижевнице (ур.). Срйкиња:

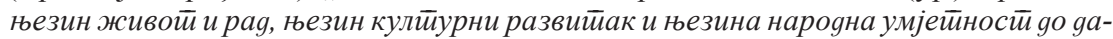
нас. Сарајево: Пијуковић и друг, 1913: 67-69.

Гавриловић Драга. Сабрана gела. Кю. 1, Песме, йрийовейке. Прва књига. Владимир Миланков (ур).Кикинда : Књижевна заједница Кикинде, 1990а.

Гавриловић Драга. Сабрана gела, Прийовеӣке, Девојачки роман. Друїа књиі̄а. Владимир Миланков (ур). Кикинда: Књижевна заједница Кикинде, $1990 б$.

Гавриловић Драга. Изабрана йроза, Јасмина Ахметагић (прир.). Београд: Мултинационални фонд културе: Конрас, 2007.

Глишићева Ђ. Станка. Моје усйомене. Београд: СКЗ, 1933.

Кинђић Зоран. "Критички осврт на разликовање знања и вере”. Кулйура 134 (2012): 388-394.

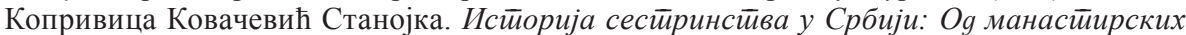

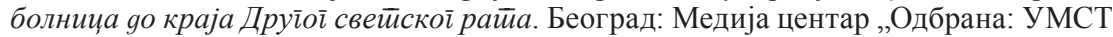
КЦС „Сестринство“: Лицеј, 2018.

Лазаревић К. Лаза. Целокуйна gела, свеска 1. Владан Недић и Бранимир Живојиновић (ур.). Београд: САНУ, 1986. 
Магазиновићева Мага. „Станка Глишић“. Српске књижевнице (ур.). Срӣкиња: њезин

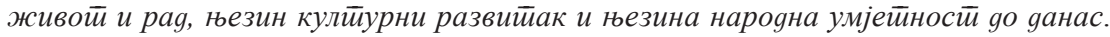
Сарајево: Пијуковић и друг, 1913: 70-71.

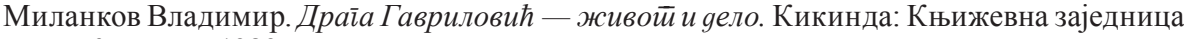
Кикинде, 1989.

Миланков Владимир. „Драга Гавриловић“. Владимир Миланков (ур.). Сабрана gела.

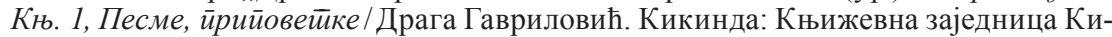
кинде, 1990: 7-12.

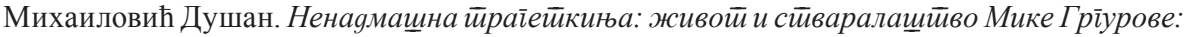
йовоgом 170-і̄oguщиғице рођења. Зоран Т. Јовановић (ур.). Нови Сад: Позоришни музеј Војводине, 2011.

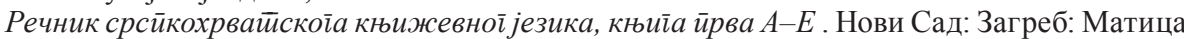
српска: Матица хрватска, 1967.

Сремац Стеван. Зона Замфирова. Нови Сад: Дневник, 2003.

Срӣски ірађански законик (1844-1946) https://sr.wikisource.org/wiki/Српски_грађански_ законик_-_оригинал

Станков Љиљана. Кайарина Миловук (1844-1913) и женски йокреӣ у Србији. Београд: Педагошки музеј, 2011.

Стојаковић, Гордана. Савка Суботић (1834-1918): Жена која није нищйиа йрећуйала. Нови Сад: Академска књига, 2018.

Столић Ана. “Савка Суботић - Слика једног света”. Савка Суботић, Усйомене, Ана Столић (прир.). Београд: СКЗ, 2001: 19-28.

Столић Ана. Сесйре Срӣкиње: йојава йокрейа за еманц̧ийацију жена и феминизма у Краљевини Србији. Београд: Еволута, 2015.

Суботић Савка. Усйомене. Ана Столић (прир.). Београд: СКЗ, 2001.

Томић Светлана (ур.). Валоризација разлика: зборник раяова са научно̄ скуйа о Драйи Гавриловић (1854-1917). Београд. Алтера: Мултинационални фонд културе, 2013.

Томић Светлана. „Значај књижевног стваралаштва Милке Гргурове““ Милка Алексић

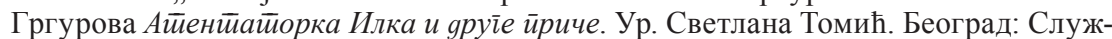
бени гласник, 2014в: 425-52.

Томић Светлана. „Хронологија живота и рада Милке Алексић Гргурове (1840-1924)”. Речи 1 (2014г): 176-88.

Црвенчанин Вера. Свит̄ања и суйон Милке Грйурове. Београд: Музеј позоришне уметности Србије, 2003.

A. V. (Arkadije Varađanin). „Mileva Simićeva“. Srpske književnice (ur.). Srpkinja: njezin život i rad, njezin kulturni razvitak i njezina narodna umjetnost do danas. Sarajevo: Pijuković i drug, 1913: 67-69.

Gavrilović Draga. Sabrana dela. Knj. 1, Pesme, pripovetke. Prva knjiga. Vladimir Milankov (ur).Kikinda : Književna zajednica Kikinde, 1990a.

Gavrilović Draga. Sabrana dela, Pripovetke, Devojački roman. Druga knjiga. Vladimir Milankov (ur). Kikinda: Književna zajednica Kikinde, 1990 b.

Gavrilović Draga. Izabrana proza, Jasmina Ahmetagić (prir.). Beograd: Multinacionalni fond kulture: Konras, 2007.

Glišićeva Đ. Stanka. Moje uspomene. Beograd: SKZ, 1933.

Kinđić Zoran. "Kritički osvrt na razlikovanje znanja i vere”. Kultura 134 (2012): 388-394.

Koprivica Kovačević Stanojka. Istorija sestrinstva u Srbiji: Od manastirskih bolnica do kraja Drugog svetskog rata. Beograd: Medija centar „Odbrana: UMST KCS „Sestrinstvo“: Licej, 2018.

Lazarević K. Laza. Celokupna dela, sveska 1. Vladan Nedić i Branimir Živojinović (ur.). Beograd: SANU, 1986.

Magazinovićeva Maga. „Stanka Glišić“. Srpske književnice (ur.). Srpkinja: njezin život i rad, njezin kulturni razvitak i njezina narodna umjetnost do danas. Sarajevo: Pijuković i drug, 1913: 70-71. 
Milankov Vladimir. Draga Gavrilović — život i delo. Kikinda: Književna zajednica Kikinde, 1989.

Milankov Vladimir. „Draga Gavrilović“. Vladimir Milankov (ur.). Sabrana dela. Knj. 1, Pesme, pripovetke/Draga Gavrilović. Kikinda : Književna zajednica Kikinde, 1990: 7-12.

Mihailović Dušan. Nenadmašna tragetkinja: život i stvaralaštvo Mike Grgurove: povodom 170-godišnjice rođenja. Zoran T. Jovanović (ur.). Novi Sad: Pozorišni muzej Vojvodine, 2011.

Rečnik srspkohrvatskoga književnog jezika, knjiga prva A-E . Novi Sad: Zagreb: Matica srpska: Matica hrvatska, 1967.

Sremac Stevan. Zona Zamfirova. Novi Sad: Dnevnik, 2003.

Srpski građanski zakonik (1844-1946) https://sr.wikisource.org/wiki/Српски_грађански_ законик_-_оригинал

Stankov Ljiljana. Katarina Milovuk (1844-1913) i ženski pokret u Srbiji. Beograd: Pedagoški muzej, 2011.

Stojaković, Gordana. Savka Subotić (1834-1918): Žena koja nije ništa prećutala. Novi Sad: Akademska knjiga, 2018.

Stolić Ana. "Savka Subotić - Slika jednog sveta". Savka Subotić, Uspomene, Ana Stolić (prir.). Beograd: SKZ, 2001: 19-28.

Stolić Ana. Sestre Srpkinje: pojava pokreta za emancipaciju žena i feminizma u Kraljevini Srbiji. Beograd: Evoluta, 2015.

Subotić Savka. Uspomene. Ana Stolić (prir.). Beograd: SKZ, 2001.

Tomić Svetlana (ur.). Valorizacija razlika: zbornik radova sa naučnog skupa o Dragi Gavrilović (1854-1917). Beograd. Altera: Multinacionalni fond kulture, 2013.

Tomić Svetlana. „Značaj književnog stvaralaštva Milke Grgurove.“ Milka Aleksić Grgurova Atentatorka Ilka i druge priče. Ur. Svetlana Tomić. Beograd: Službeni glasnik, 2014v: 425-52.

Tomić Svetlana. „Hronologija života i rada Milke Aleksić Grgurove (1840-1924)”. Reči 1 (2014g): 176-88.

Crvenčanin Vera. Svitanja i suton Milke Grgurove. Beograd: Muzej pozorišne umetnosti Srbije, 2003.

Светлана Томић

ИНТЕЛЕКТУАЛКЕ У СРПСКОЈ КУЛТУРИ 19. ВЕКА И ЮИХОВА ВЕРОВАњА:
ЗНАЧАЈ ДИСКОНТИНУИТЕТА

Резиме

Предмет овог рада је анализа белетристичких и документаристичких радова истакнутих интелектуалки које су деловале у Србији и Аустроугарској монархији у другој половини 19. века, периоду који многи историчари сматрају кључним за модернизацију српског друштва. Савка Суботић и краљица Наталија Обреновић, прве учитељице и књижевнице, попут Станке Глишић, Драге Гавриловић и Милеве Симић, као и глумица Милка Алексић Гргурова, представиле су веровања која су била супротна владајућој догми. Веровале су да је образовање жена потребан чинилац друштвеног напретка. Биле су свесне где лежи моћ конзервативизма, разумеле су да је успех еманципације жена могућ у будућности само ако се еманципују мушкарци. Сматрале су да брак не сме бити конципиран без љубави и узајамног поштовања, а одобравале су и мешовите бракове, што је тада било готово јеретично схватање. Главна теза овог рада је да је дисконтинуитет у веровању, као фундаментални елеменат модернизације, наступио захваљујући интелектуалкама.

Кључне речи: веровање, образовање жена, еманципација жена, српска књижевност, историја српског друштва. 